\title{
Parasitic helminthes - probable cause of death of birds
}

\author{
A. OKULEWICZ ${ }^{1}$, J. SITKO ${ }^{2}$
}

\author{
${ }^{1}$ Department of Parasitology, Institute of Genetics and Microbiology, Wrocław University, \\ Przybyszewskiego 63/77, 51-148 Wrocław, Poland, E-mail: anna.okulewicz@microb.uni.wroc.pl; \\ ${ }^{2}$ Comenius Museum, Horni nam. 7, 75152 Přerov, Czech Republic, E-mail: sitko@cmail.cz
}

\begin{abstract}
Summary
Parasitic helminths were the probable cause of death of 41 passeriform birds (29 adults and 12 juveniles in their first year of life) caught in the net during the spring and autumn ringing (1986 - 2010). The birds (1 Chaffinch Fringilla coelebs, 1 House Martin Delichon urbica, 2 Blue Tit Cyanistes caeruleus, 9 Great Tit Parus major, 3 Willow Tit Poecile palustris, 1 Great Reed Acrocephalus arundinaceus, 1 Chiffchaff Phylloscopus collybita, 3 Blackcap Sylvia atricapilla, 2 Dunnock Prunella modularis, 1 Magpie Pica pica, 5 Robin Erithacus rubecula, 9 Common Blackbird Turdus merula and 3 Song Thrush T. philomelos) were caught in the environs of Přerov (Czech Republic). The helminths: trematodes, tapeworms, nematodes and hook worms, were located in the intestine, glandular and muscular stomach, cloaca, rectum, gall bladder, liver, pulmonary cavity, air sac, nasal and orbital cavity and subcutaneous tissue of the hosts. The intensity of invasion with different species of parasites was up to 734 per host. Some parasites Brachydistomum ventricosum, Mosesia sittae, Aprocta cylindrica, Diplotriaena tridens were acquired at the wintering grounds. All the helmniths were heteroxenous, with development cycle involving intermediate hosts (invertebrates) which are part of the birds' diet.
\end{abstract}

\section{Introduction}

Parasitic invasions are known to cause death of domestic birds. Parasites of respiratory system seem to be the most pathogenic. An example is a blood-sucking nematode Syngamus trachea causing syngamosis which, for example, was the cause of as much as $80 \%$ mortality of pheasants in a breeding stock in Mid/Central Pomerania (Poland) (Wójcik et al., 1999). Sections showed the presence of about a dozen to thirty pairs of $S$. trachea, whose females reach up to 20 $\mathrm{mm}$ and males up to $4 \mathrm{~mm}$ length. The most infected birds had their tracheal bifurcation blocked. The organ showed a local inflammation of mucosa, with ulcers.
In the case of wild-living birds it is difficult to ascertain if parasitic invasions contribute to the hosts' death and which species of helminths are involved. According to the Polish scientist W. Wiśniewski 1955 (according to Pojmańska \& Niewiadomska, 2010) the host has a certain parasite capacity. When this critical value is exceeded, and too much energy is transferred from the host to the parasites, the host dies. Large wild-living birds are able to survive in relatively good condition even when they carry enourmous numbers of intestinal parasites of small size. For example, in adult cormorants Phalacrocorax carbo, shot in their breeding colony at the Vistula Bar (Poland), the maximum infection was 3300 small trematodes Petasiger phalacrocoraxi (2 - $3 \mathrm{~mm}$ length) and 5773 tapeworms Paradilepis scolecina (to $7 \mathrm{~mm}$ length) in individual birds (Kanarek, 2007). Smaller birds (most Passeriformes) seem to be less resistant to mass helminth invasions. This depends on the parasite location, size and intensity of invasion.

Dead passerine birds are rarely found in the wild; they most often fall prey to predators and it is difficult to ascertain the cause of their death. However, during ringing, in the period of spring and autumn migrations, some birds falling into nets and exhausted by the journey, die and then parasitological section can with high probability point to intense parasite invasions combined with stress as the cause of death. Death of healthy birds during ringing is very rare (e.g. strangulation as a result of getting entangled in the nets).

\section{Materials and methods}

From 1986 to 2010 - 41 passeriform birds were subject to parasitological section: 1 Chaffinch Fringilla coelebs (Fringillidae); 1 House Martin Delichon urbica (Hirundinidae); 2 Blue Tit Cyanistes caeruleus, 9 Great Tit Parus major, 3 Willow Tit Poecile palustris (Paridae); 1 Great Reed Acrocephalus arundinaceus, 1 Chiffchaff Phyllosco- 
pus collybita, 3 Blackcap Sylvia atricapilla (Sylviidae); 2 Dunnock Prunella modularis (Prunellidae); 1 Magpie Pica pica (Corvidae); 5 Robin Erithacus rubecula, 9 Common Blackbird Turdus merula and 3 Song Thrush T. philomelos (Turdidae) caught in the environs of Přerov (Czech Republic). All these birds died in the nets during spring or autumn ringing. The section was done according to the standard methods. The birds included 11 females $(\mathrm{F}), 18$ males (M) and 12 juveniles in the first year of life (1 y) (Table 1).

\section{Results}

Among the 41 passeriform birds whose likely cause of death were helminths included 12 juveniles (1 y) - 29.3\% and 29 adultus $-70.7 \%$ : 18 males (M) and 11 females (F). Twenty one birds showed intense mono-species invasions, twenty - intense coinvasions of $2-4$ parasite species. Invasions of 4 helminth species (trematodes, cestodes, nematodes and acantocephales) in one bird occurred only in Turdus merula. The most intensive invasions (up to 734 specimens) were those by trematodes, followed by tapeworms (up to 388 specimens) and nematodes (up to 179 specimens); hook worms showed numbers of $14-22$ specimens per host. The helminths were mainly located in the intestine, but also in glandular and muscular stomach, cloaca, rectum, gall bladder, liver, pulmonary cavity, air sac, nasal and orbital cavity, and also subcutaneous tissue (Table 1).

All the helminths found in the examined birds were heteroxenous - with complex life cycles involving intermediate hosts - invertebrates which form a part of the hosts' diet. It was characteristic that in small-sized birds $-A$. arundinaceus, D. urbica, E. rubecula, F. coelebs, $P$. palustris, $S$. atricapilla - almost exlusively one-parasite-species invasions per host occurred. The parasites were trematodes Brachydistomum ventricosum, Collyriclum faba, Leucochloridium paradoxum, L. perturbatum, Plagiorchis maculosus or nematodes Aprocta cylindrica, Diplotriaena tridens. Only 3 of the 9 Parus major and 1 of the 2 examined $C$. caeruleus, besides intensive intestinal invasions of the trematode Leucochloridium paradoxum (from 56 to $148)$ or Urogonimus macrostomus, contained few $(6-14)$ tapeworms Anonchotaenia globata.

Birds become infected with some parasite species only during their stay in the wintering grounds. Such parasites were never found in juvenile birds obtained during the autumn migrations; they occurred only in adult birds. Such parasites included trematodes Mosesia sittae and Brachydistomum ventricosum or nematodes $A$. cylindrica and $D$. tridens.

Mosesia sittae is a parasite of unknown life cycle. Invasion of 259 specimens of this small parasite (size $0.5 \times 0.3 \mathrm{~mm}$ ) probably contributed to death of $1 \mathrm{~F}$ Prunella modularis caught in March 2001. Trematodes B. ventricosum were noted in adult (F and $\mathrm{M})$ E. rubecula during their spring migration (April); the intensity of invasion was 92 and 291 specimens. These trematodes, parasites of gall bladder, reach a size of $6 \times 1 \mathrm{~mm}$ and it is hard to imagine how they fit into the small bird's organ. Intermediate hosts of the parasite are land snail of the genus Allogona and ants of the genus Camponotus.

Nematodes $A$. cylindrica and $D$. tridens, despite their different localisation in the bird's organism, share the intermediate host - locust Locusta migratoria. Migratory Turdidae, Fringillidae, Oriolidae, Muscicapidae, Motaciilidae, Sylvidae, Laniidae, Pariidae from Central Europe become infected with these helminths during wintering in southwestern Europe (mainly Iberian Peninsula), northern Africa and Asia Minor.

Nematode Aprocta cylindrica, with female body size up to $19 \mathrm{~mm}$ length and $0.57 \mathrm{~mm}$ width, and males of $10.3 \mathrm{~mm}$ and $0.37 \mathrm{~mm}$ respectively, is located in the nasal and orbital cavity. In the examined material they were found in 3 adult $E$. rubecula (intensity $28-36$ specimens). The infected Robins were characterised by exophthalmus and the presence of mucus in the nasal cavity; the mucus leaked out through the beak. The birds were breathing with difficulty, through open beak.

Death of 2 M Sylvia atricapilla caught during the spring migration was probably caused by nematode $D$. tridens, which reaches considerable size: females to $26 \mathrm{~mm}$, males to $19 \mathrm{~mm}$ length, at the maximum width of $0.61 \mathrm{~mm}$. It is noteworthy that one Blackcap had 138 specimens of the parasite in its pulmonary cavity. The bird's general condition was bad, it was emaciated, with a thinned plumage. Its air sacs were non-functional (filled with nematodes) and contained mucus.

Intestinal trematodes Leucochloridium paradoxum and $L$. perturbatum were the most frequent parasites in the examined birds, caught both in the spring and autumn period. The invasion intensity ranged from 56 to 734 specimens, and they were found in 1 (M) F. coelebs, 2 (1y) C. caeruleus, 8 (1F, 5M, 2 (1y) P. major, 3 (1F, 2 1y) P. palustris, 1 (1y) Ph. collybita, 1 (M) P. modularis, 1 (F) S. atricapilla, 7 (3F, 2 M, 2 (1y) T. merula and 2 (1 y) T. philomelos. These two related trematode species reach the size of only $2 \times 1 \mathrm{~mm}$, but can cause inflammatory condition of the intestine, leading to the loss of ability to feed, emaciation and inability to fly. Their intermediate hosts are land snails Succinea putris and S. pfeifferi.

Trematode Collyriclum faba is a parasite of subcutaneous tissue of Passeriformes, is intermediate hosts are snails and water insects (Odonata, Plecoptera, Ephemeroptera, Trichoptera). C. faba of a size of $2-3 \mathrm{~mm}$, occurs in cysts located on the legs, trunk, abdomen, near the anus, at the base of wings and in the region of eye. In our material, in 1 M A. arundinaceus in 15 cysts of $6-8 \mathrm{~mm}$ diameter, located on the abdomen around the cloaca, 30 parasites were found, two per cyst; the cysts probably contributed to the bird's death. The Great Reed, in spite of considerable emaciation, had a swollen abdomen and very much damaged main feathers with marked lighter stripes.

Larger passerines are more resistant to parasite invasions. However, their death may be caused by coinvasions of several helminth species located in various organs. The 


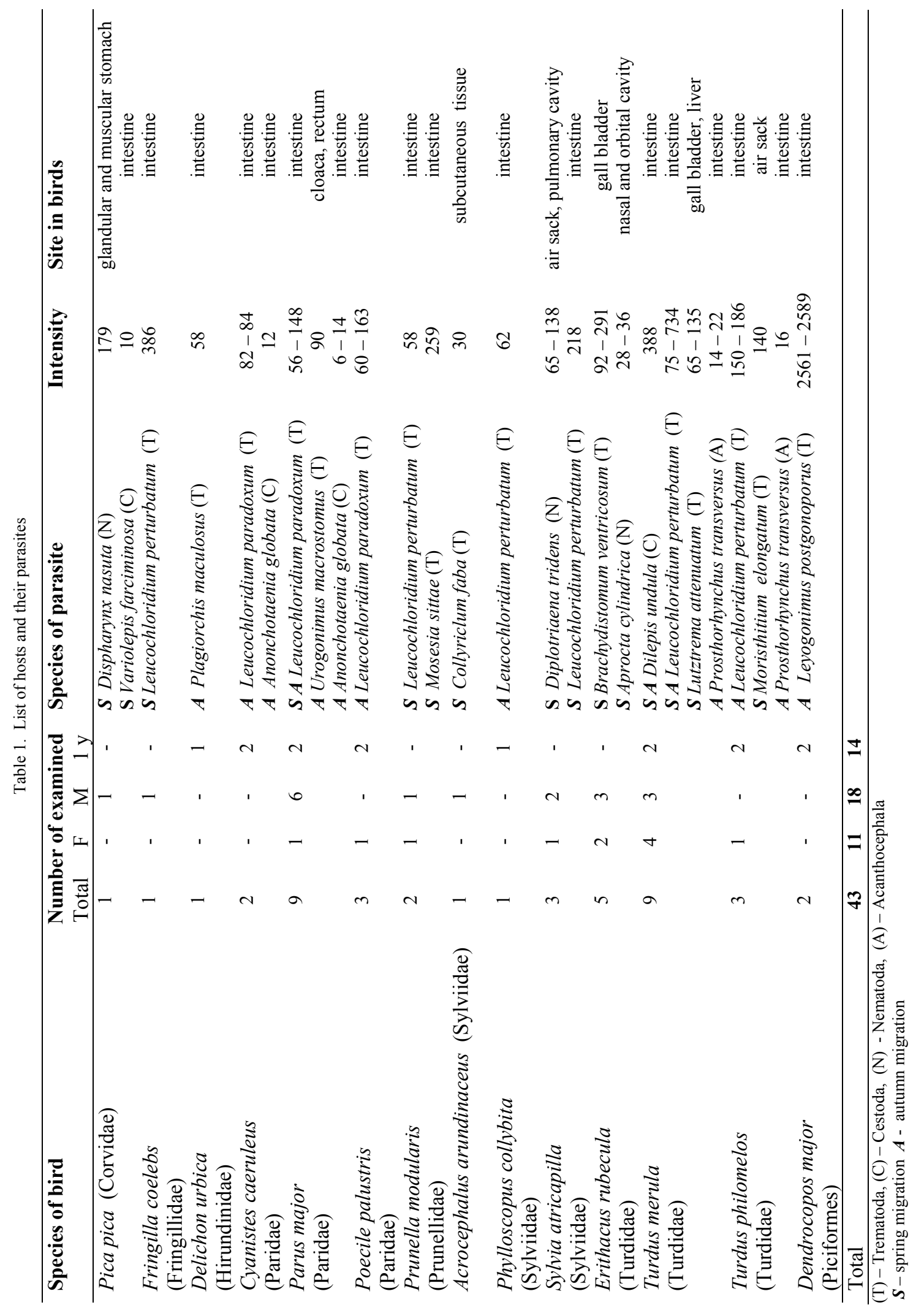


death of 1 (M) Pica pica was probably a consequence of infection with 179 specimens of nematode Dispharynx nasuta, since 10 tapeworms Variolepis farciminosa probably did not cause significant pathological changes in the bird's intestine. D. nasuta (body length of female to $9.2 \mathrm{~mm}$ and male to $8 \mathrm{~mm}$ ) are parasites of mucosa or walls of proventriculus of gallinaceus and passerinae birds, causing dangerous inflammatory conditions. The intermediate hosts of this nematode are isopods (Porcellio, Armadillidium).

The death of Blackbirds and Song Thrushs, both adult and juveniles (1 y), was probably caused by multispecies invasions. Besides intestinal parasites - trematodes Leucochloridium perturbatum (intensity 75 - 734 specimens), tapeworms Dilepis undula (intensity 6 - 388) and hook worms Prosthorhynchus transversus (intensity $14-22$ specimens), in 4 adult (3F and $1 \mathrm{M}$ ) Blackbirds the gall bladder and liver contained trematodes Lutztrema attenuatum (intensity $7-135$ ) of a size of $4 \times 0.3 \mathrm{~mm}$. Pathogenic effect of acanthocephalans (length to $14 \mathrm{~mm}$ ) are due to the deep penetration of the intestinal wall by their proboscises (length to $1.3 \mathrm{~mm}$ ) with spines.

It is noteworthy that in a female Song Thrush (obtained on 31 March 2009) the air sac contained 140 trematodes Moristhitium elongatum (size $16 \times 4 \mathrm{~mm}$ ), the intestine 68 tapeworms Dilepis undula (length up to $28 \mathrm{~mm}$ ) and the gall bladder - 5 trematodes L. attenuatum. The bird's condition was very poor, it was emaciated and died soon after falling into the net.

Parasites found in juvenile and adult Passeriformes caught in the Czech Republic were trematodes Leucochloridium perturbatum, L. paradoxum, Urogonimus macrostomus. Plagiorchis elegans and P. maculosus. Their intermediate hosts from which the birds acquire the parasites are land snails of the genera Succinea, Clausilia, Vallonia and larvae of aquatic insects.

\section{Discussion}

The presented data show that not only intense helminth invasions are the cause of pathological changes leading to the host's death. Sometimes even a small number of parasites large-sized may cause intestine or air ducts blockage. In our studies this was caused by 30 trematodes Collyriclum faba in the cysts located near the cloaca, which led to the intestine blockage in $A$. arundinaceus. A similar case was reported by Literak et al. (2003) where only 14 cysts of the trematode located in the same way caused emaciation and death of Grey Wagtail Motacilla cinerea. The birds become infected by the parasite during their spring migrations in the mountainous regions of south-western Europe (Alps, Apennines) and autumn migrations in the Central European Carpathians (Literak \& Sitko, 2006).

Also nematode Aprocta cylindrica, located in the nasal and orbital cavity, can be dangerous especially for E. rubecula. In the Robin in Central Europe the nematode is recorded the most frequently and with the greatest intensity (Okulewicz, 1984; Frantova, 2002, Sitko \& Okulewicz, 2010).
Anatomical characters of the Robin - relatively large head and well developed eye sockets, and also the diet including mainly insects and their larvae, seem to explain this.

Trematodes located in the gall bladder and bile ducts show a great pathogenicity in their hosts. In passerine birds they are Brachydistomum ventricosum and Lutztrema attenuatum. Trematodes located in these organs can contribute to death of even large birds. For example Kron et al. (2003) report death of 6 individuals of White-tailed Sea Eagle Haliaeetus albicilla in Germany, probably caused by liver fluke infection with Metorchis bilis.

Intestinal parasites, especially small-sized, are less dangerous for birds, and even when numerous they may not cause pathological symptoms and not affect the host's behaviour. For example, in killed on the road female Blackbird Turdus merula found in the environs of Wrockaw (Poland), the intestine contained 1290 nematodes - intestinal capillariae Baruscapillaria ovopunctata. Despite this the bird was not emaciated, and even bred which was indicated by the so called breeding spots on its belly (Okulewicz, 1991). Also invasion of 1297 specimens of intestinal flukes Neodiplostomum attenuatum (length $1.6-2.6 \mathrm{~mm}$ ) in adult Buteo buteo electrocuted as a result of collision with power line seemed to have no effect on the bird's condition (Sitko, 1998).

The most frequent helminths, found in 26 of the 41 examined birds, were intestinal flukes of the genus Leucochloridium. The intensity of invasion ranged from 75 to 734 specimens. They occurred in the insectivorous birds of the families Fringillidae, Paridae, Prunellidae, Sylviidae and Turdidae. Trematode larvae - metacercariae in sporocysts - are located in tentacles of snails of the genus Succinea. Infected snails have elongated and distended tentacles, with a colour pattern of transverse stripes; the tentacles pulsate rhythmically. Insectivorous birds often catch and swallow these fly larvae- or caterpillar-resembling tentacles (Niewiadomska et al., 2001).

When the number of Leucochloridium flukes in the intestine of small passeriform birds, with the intestine length of ca. $150 \mathrm{~mm}$, is great (about 100 specimens) they lead to emaciation which may cause death, also because of chilling resulting from the lack of adipose tissue (Sitko, unpubl. data).

Multispecies helminth invasions in Turdidae are associated with their varied diet, which includes, among others, such invertebrates as earthworms, terrestrial snails, terrestrial isopods, millipedes and grasshoppers (Calegaro-Marques \& Amato, 2010).

The size of the bird host is also important for the effects of the parasite invasion. Mass invasions of many helminth species are especially frequent in aquatic birds (Anseriformes). For example, as many as 24 helminth species occurred in the alimentary tracts of 25 eider ducks (Somateria mollisima) found dead on the coast of the North Sea or the Wadden See. The intensity of invasion of some parasites per individual bird host is enormous: nematodes - Amidostomum acutum (max. 1500), Capillaria nyrocinarum (max. 1700); trematodes - Cryptocotyle concavum (max. 10 000), Psilotrema simillimum (max. 10 000); tapeworms Hyme- 
nolepididae (max. 4000); hook worms - Profillicolis botulus (max. 4000) - (Borgsteede et al., 2005). The authors suppose that the reason for the death of the eider ducks was invasion of these helminths, and point to the fact that the most pathogenic among them are blood sucking nematodes of the genus Amidostomum located below the corneous membrane of the muscular stomach. Probably mass invasions, even up to 3500 individuals, of nematode Contracaecum multipapillatum, of female size up to $30 \mathrm{~mm}$ length and $0.77 \mathrm{~mm}$ width in brown pelican Pelecanus occidentalis caused death of 23 birds in Porto Rico (Dyer et al., 2010). Highly pathogenic helminths include intestinal hook worms whose spine-armed rostra deeply penetrate the intestine mucosa and cause inflammatory condition and sometimes even perforation. Acanthocephalodiosis caused by Profilicollis chasmagnathi in Olrog's Gull Larus atlanticus in Argentina was reported by La Sala et al. (2007). Invasions of $6-234$ hook worms per host caused death of many juveniles in a breeding colony.

Our results show that helminth invasion was the probable cause of death of males of passeriform birds $(62.1 \%)$ more often than of females $(37.9 \%)$; invasions of two or more parasite species occurred in males more often than in females. These observations confirm the rule that males are usually more intensely infected with parasites than females (Deviche et al., 2001). This is a result of synergistic action of ecological, behavioural and immunological factors (Klein, 2000). However, the most important role in causing the higher parameters of helminth occurrence in male birds is attributed to the higher testosterone level (immunosupression), which affects mainly humoral immunological response (Hillgarth \& Wingfield, 1997). The greater species richness of helminths in males compared to females of rufous-bellied trush Turdus rufiventris from Brazil was demonsttrated also by Calegaro-Marques \& Amato (2010). Our own studies (Sitko, unpubl. data) show that passeriform females, especially of the family Turdidae, are more frequently infected with teematodes Lutztrema attenuatum and Moristhitium elongatum than males. This may result from feeding preferences: they prefer Crustacea and Mollusca (which may contain trematode metacercariae) containing calcium necessary to build egg shells.

Thus, causes of "natural" death of birds, besides thermal shock, territorial fights, malformation and starvation, include also bacterial and parasitological infections, and especially intensive invasions by large-sized helminths.

\section{Acknowledgement}

This study was made possible by project of Czech Republic (DE 07 PO4OM G 007) support of scientific research of the Ministry of Education.

\section{References}

Borgsteede, F. H. M., OKulewicz, A., Zoun, P. E. F., OKULEWICZ, J. (2005): The gastrointestinal helminth fauna of the eider duck (Somateria molissima L.) in the Netherlands. Helminthologia, 42, 2: $83-87$
Calegaro-Marques, C., Amato, S. B. (2010): Parasites as secret files of the trophic interactions of hosts: the case of the rufous-bellied trush. Rev. Mex. Biodivers., 81: $801-$ 811

Deviche, P., Greiner, E. C., Manteca, X. (2001): Seasonal and age-related changes in blood parasite prevalence in Dark-Eyed Juncos (Junco hyemalis, Aves, Passeriformes). J. Exp. Zool., 289: 456 - 466. DOI 10.1002/jez.1027

Dyer, W. G., Williams JR, E. H., Mignucci-Giannoni, A. A., Jimenez-Marrero, N. M., Bunkley-Williams, L., Moore, D. P., Pence, D. B. (2010): Helminth and arthropod parasites of the brown pelican, Pelecanus occidentalis, in Puerto Rico, with a compilation of all metazoan parasites reported from this host in the Western Hemisphere. Avian Pathol., 31: 5, 441 - 448. DOI 10.1080/0307945021000005815

Frantova, D. (2002): Some parasitic nematodes (Nematoda) of birds (Aves) in the Czech Republic. Acta Soc. Zool. Bohem., 66: $13-28$

Hillgarth, N., Wingfield, J. C. (1997): Parasite-mediated sexual selection: endocrine aspects In: CLAYTON, D. H., MoOre, J. (Eds) Host-Parasite Evolution. General principles and avian model. Oxford University Press: 78 - 104 KLEIN, S. L. (2000): The effects of hormones on sex differences in infection: from genes to behavior. Neurosci Biobehav. Rev., 24: 627 - 638. DOI 1016/SO149-7634(00) 00027-0

KANAREK, G. (2007): [Helminth fauna of the great cormorant (Phalacrocorax carbo sinensis) in northern Poland]. Dissertation in Department of Invertebrate University of Gdansk

Krone, O., Langgemach, T., Sommer, P., Kenntner, N. (2003): Causes of mortality in white-tailed sea eagles from Germany. In: Helander, B., MARQuiss, M., Bowerman, W. (Eds) Sea Eagle 2000: Proceeding of Swedish Society for Natural Conservation. SNF, Stockholm, Sweden, 211 218

LA Sala, L. F., Martorelli, S. R. (2007): Intestinal Acanthocephaladiosis in Olrog's Gull (Larus atlanticus): Profilicollis chasmagnathi as possibile causa of Heath. J. Wildl. Dis., 43 (2): $269-273$

LiteraK, I., Honza, M., HaluziK, M., Haman, A., PinOwsKA, B., Pcola, S. (2003): Cutaneous Trematode Collyriclum faba in Wild Birds in the Central European Carpathians. J. Parasitol., 89 (2): 412 - 416. DOI 10.1017/JOH 2006362

LiTERAK, I., SiTKO, J. (2006): Where in Europe should we look for sources of the cutaneous trematode Collyriclum faba infections in migrating birds? J. Helminthol., 80: 349 $-355$

Niewiadomska, K., Pojmańska, T., Machnicka, B., Czubaj, A. (2001): [Outline of General Parasitology]. Wyd. Naukowe PWN, Warszawa, 515 pp. (In Polish)

OKULEWICZ, A. (1984): [The parasitic nematodes of the Robin (Erithacus rubecula L.) from the region of Wrocław]. Wiad. Parazytol., 30, 5 - 6: 585 - 594 (In Polish) OKULEWICZ, A. (1991): [Turdus merula L. as a proper host 
for Capillaria ovopunctata (Nematoda: Capillariidae)]. Wiad. Parazytol., 37 (2): 261 - 267 (In Polish)

PoJMAŃSKA, T., NiEWIAdOMSKA, K. (2010): [Parasites inconvenient element in the structure of ecosystem food web]. Kosmos, 1 - 2: 99 - 110 (In Polish)

SiTKO, J. (1998): Trematodes of birds of prey (Falconiformes) in Czech Republic. Helminthologia, 35, 3: 131 - 146
SitKo, J., OKUlewiCZ, A. (2010): Checklist of the Nematodes in Birds in the Czech Republic and the Slovak Republic. Comenius Museum, Přerov.

WÓJCIK, A. R., WASILEWSKI, L., GRYGON-FrANCKIEWICZ B., ŻBIKOWSKA, E. (1999). [Economic losses in pheasant breeding evoked with endoparasites]. Wiad. Parazyt., 45 (3): 363 - 368 (In Polish) 